\title{
PEMBELAJARAN BAHASA SEBAGAI UPAYA MENINGKATKAN KEMAMPUAN LITERASI SISWA
}

(Jurnal Penelitian Tindakan Sekolah)

Oleh

Yanto Budhianto, M.M.

Kepala SDN 1 Kalapagunung Kecamatan Kramatmulya

Post-El. budhianto71@gmail.com

\begin{abstract}
ABSTRAK
Gerakan Literasi merupakan kegiatan yang bersifat partisipatif melibatkan seluruh warga sekolah (peserta didik, Guru, Kepala sekolah, tenaga kependidikan, pengawas sekolah, Komite sekolah, dan orang tua wali murid). Hal ini terkait dengan pembelajaran yang dilaksanakan di sekolah bahwa Literasi identik dengan aktifitas membaca dan menulis mencakup bagaimana seseorang berkomunikasi dalam masyarakat. Literasi juga bermakna praktik dan hubungan sosial yang terkait dengan pengetahuan, bahasa, dan budaya (UNESCO, 2003).

Kemampuan Siswa sebagai subjek pembelajar dalam Gerakan Literasi Sekolah diantaranya kemampuan menentukan, mengidentifikasi , menemukan, mengevaluasi, menciptakan Informasi secara terorganisir guna mengkomunikasikannya pada tiap individu untuk berpartisifasi aktif dalam belajar di sekolah dan di masyarakat

Gerakan kolaboratif pembelajaran berbahasa di SDN 1 Kalapagunung ditekankan dalam pengefektifan Literasi dengan mewujudkan pembiasaan membaca peserta didik dalam waktu 15 menit membaca mampu mengarahkan pengembangan belajar pada tahap keterampilan reseptif, produktif maupun responsif Siswa.

Pembelajaran berbahasa, pada Penelitian Tindakan Sekolah yang dilaksanakan di SDN 1 Kalapagunung bertujuan untuk meningkatkan Kemampuan Literasi tiap peserta didik melalui cara dan teknik pengajaran yang dilaksanakan Guru dalam memanfaatkan sumber daya yang ada untuk menumbuhkembangkan budaya Literasi di SDN 1 Kalapagunung
\end{abstract}

\section{Kata Kunci : Pembelajaran Bahasa, Kemampuan Literasi}




\section{PENDAHULUAN}

Keterampilan berbahasa merupakan faktor yang penting dalam proses pembelajaran, karena dengan berbahasa peserta didik dapat memperoleh informasi. Keterampilan berbahasa yang paling dasar adalah Membaca, menulis, mennyimak dan berkomunikasi. Unsur keterampilan ini merupakan faktor pendukung pada kegiatan dalam berliterasi. Literasi menjadi sarana peserta didik dalam mengenal, memahami, dan menerapkan ilmu berbahasa yang didapatkan di bangku sekolah.

Perkembangan pembelajaran bahasa dalam mendukung pelaksanaan Gerakan Literasi menumbuhkembangkan pembiasaan berbahasa yang mempunyai kekhasan menyangkut hal inti dalam mempelajari setiap ilmu formal melalui proses membaca dan menulis bahasa lisan. Pembelajaran ini merupakan suatu proses mengkonstruksi pengetahuan melalui keterlibatan fisik dan mental siswa secara aktif dalam mengasimilasikan dan menghubungkan bahan dengan pengalaman siswa Pembelajaran bahasa secara keseluruhan pembelajaran mempengaruhi perkembangan pembelajaran bahasa, baik dari sisi teori, pendekatan, metode, strategi, dan lain sebagainya yang berhubungan dengan proses pembelajaran bahasa itu sendiri.

Mencermati kondisi kegiatan pembelajaran bahasa terutama dalam membaca dan menulis pada pengembangan kegiatan Literasi di SDN 1 Kalapagunung perlu dilakukan penelitian yang bersifat reflektif dengan melakukan tindakan yang direncanakan, dilaksanakan dan dievaluasi. guna mengubah suasana pembelajaran ke arah pembelajaran yang lebih memungkinkan siswa terlibat secara aktif dan menyenangkan.

\section{METODE PENELITIAN}

Metode Penelitian yang diterapkan dalam Penelitian Tindakan Sekolah ini adalah dengan menggunakan metode Deskriptif kualitatif yang diambil dari hasil observasi pembelajaran bahasa di kelas dan pengalaman pembiasaan Budaya Literasi siswa di sekolah dengan mengambil studi pustaka dari berbagai sumber pembelajaran bahasa Indonesia

Teknik analisis data yang digunakan Analisis deskripsi berdasarkan proses belajar mengajar Guru yang berlangsung dan pengumpulan data hasil observasi dokumen pembelajaran dan aktivitas siswa dalam belajar di kelas serta pembiasaan Literasi di Sekolah. Teknik analisis data dilakukan dengan reduksi 
data, penyajian data, dan verifikasi data sampai pada penarikan kesimpulan (Sugiyono, 2010). Penelitian dilaksanakan pada awal semeter 1 tahun pelajaran 2018/2019 bulan juli sampai September di SD Negeri 1 Kalapagunung Desa Kalapagunung Kecamatan Kramatmulya Kabupaten Kuningan

\section{PROSEDURE PENELITIAN}

\section{Perencanaan}

a. Penjelasan tentang tujuan dan fungsi penelitian dalam pemahaman terhadap kegiatan pembelajaran yang dilaksanakan Guru

b. Guru mempersiapkan diri untuk penyusunan Skenario pembelajaran berbahasa dengan mengkaitkan pada pengembangan budaya Literasi di Sekolah

c. Pembimbingan terhadap penyusunan Skenario Pembelajaran Guru melalui pemahaman langkah belajar berbahasa

d. Membuat lembar pengamatan keberhasilan belajar

e. Mengobservasi hasil survey terhadap aktivitas belajar berbahasa siswa yang mendukung kegiatan budaya literasi

f. Guru mempresentasikan Skenario pembelajaran dalam KBM dan evaluasi pembelajaran

g. Diskusi kelompok Guru berbagi pengalaman pelaksanaan pembelajaran berbahasa dalam menunjang dan membudayakan Literasi

h. Target yang diharapkan :

1) Guru mampu melaksanakan pembelajaran berbahasa dengan variatif teknik dan metode pembelajaran

2) Pelaksanaan pembelajaran lebih menekankan pada pemanfaatan lingkungan sekolah sebagai sumber belajar

3) Guru secara aktif berdiskusi dalam kelompok sharing pengalaman peningkatan pembelajaran bahasa dalam budaya literasi 


\section{Pelaksanaan}

\section{SIKLUS I}

a. Menyiapkan skenario penelitian dan instrumen penelitian dengan menentukan pembelajaran Berbahasa pada masing-masing Guru Kelas

b. Guru diberi arahan untuk mengambil nilai awal standar pra KBM pada pembelajaran berbahasa

c. Guru memberikan tindakan pada proses pembelajaran dengan mengambil teknik pembelajaran berbahasa pada tema pembelajaran yang disampaikan

d. Hasil pembelajaran berbahasa pada siklus I merupakan keberhasilan pertama dalam meningkatkan pengetahuan bahasa siswa

e. Hasil Nilai pembelajaran siswa jadi acuan dalam pelaksanaan pembiasaan teknik budaya Literasi sekolah

f. Aktivitas siswa dalam belajar bahasa di kelas dengan pembiasaan literasi diharapkan dapat meningkatkankemampuan Lioterasi Siswa g. Karakteristik dari pembiasaan, aktivtas, dan Nilai evaluasi siswa menunjukkan proses kegiatan pembelajaran yang harus diperbaiki atau tidak

\section{SIKLUS II}

a. Skenario pembelajaran yang disampaikan Guru dalam pembelajaran berbahasa disesuaikan dengan kemampuan siswa menangkap materi pembelajaran

b. Nilai hasil pembelajaran berbahasa Refleksi pada siklus I jadi acuan peningkatan hasil belajar selanjutnya

c. Guru membimbing siswa pada aspek pembelajaran, aktivitas dan hasil evaluasi dengan melengkapi permasalahan yang dihadapi siswa

d. Guru mempraktikan pembelajaran bahasa lanjutan sebagai perbaikan dari kelemahan pembelajaran sebelumnya

e. Guru mengecek hasil pembinaan dan praktek pembelajaran dalam kegiatan pembiasaan literasi siswa di sekolah 
f. Keberhasilan dari

pembelajaran, hasil evaluasi

dan aktivitas belajar siswa

secara oftimal menjadi resume

keberhasilan peningkatan

budaya literasi siswa di

Sekolah

g. Peningkatan budaya Literasi

Siswa di sekolah terpenuhi

apabila nilai hasil belajar lebih

tinggi dari rata-rata, kriteria

aktivitas siswa lebih aktif dan

meningkatnya minat siswa

terhadap pembiasaan budaya

Literasi di sekolah

\section{Observasi dan Evaluasi}

a. Mengamati tahap pelaksanaan pengelolaan kelas Guru mulai dari perencanaan, pelaksanaan dan evaluasi

b. Mengobservasi tingkat aktivitas siswa dalam pembelajaran berbahasa dengan mengamati kesulitan dan kelemahan dalam penyampaian materi pelajaran

c. Mengkoordinasikan hasil pengamatan aktivitas siswa di kelas dengan pembiasaan budaya litersi di Sekolah

d. Menunjukkan minat bakat siswa dari hasil koordinasi aktivitas siswa di kelas dan

diluar kelas pada

pembelajaran bahasa dan

budaya literasi

\section{Refleksi Kegiatan}

a. Mengamati nilai hasil pembelajaran bahasa dengan membandingkan

peningkatannya pada tiap kegiatan penelitian (siklus I dan II)

b. Mengamati nilai hasil aktivitas siswa dengan membandingkan peningkatannya pada tiap kegiatan penelitian (siklus I dan II)

c. Mengamati hasil observasi kegiatan pembiasaan Literasi di sekolah pada tahap kegiatan penelitian (siklus I dan II)

d. Hasil perolehan nilai belajar siswa, aktivitas siswa dan pembiasaan pada kriteria yang diperoleh menunjukkan tindak lanjut langkah perbaikan penelitian selanjutnya. 


\section{HASIL PENELITIAN}

\section{A. Hasil Pembelajaran Bahasa yang menarik}

Pembelajaran bahasa

Indonesia merupakan langkah awal dalam mengamati pelajaran lain pada jenjang pendidikan dimulai dari tingkat dasar. Pentingnya penggunaan bahasa Indonesia yang baik dan benar menjadi salah satu indikator keberhasilan pembelajaran lainnya dalam mengadaptasi lingkup kompetensi menyimak, berbicara, membaca dan menulis yang diharapkan dengan menggunakan bahasa untuk mengkomunikasikan tujuan yang diharapkan.

Pembelajaran bahasa Indonesia yang dilaksanakan di SDN 1 Kalapagunung pada kegiatan penelitian ditekankan pada pengelolaan kegiatan belajar mengajar yang dilaksanakan Guru Kelas ( kelas I - VI). Hal ini berkaitan dengan langkah-langkah guru memberikan pembelajaran bahasa dan pembiasaan Literasi di sekolah. Literasi sebagai seperangkat kemampuan mengolah informasi, jauh diatas kemampuan mengurai dan memahami bahan bacaan sekolah. Menurut Satria Darma (2014:1) bahwa Literasi dipahami sebagi kemampuan membaca dan menulis dan berkembang menjadi konsep literasi fungsional, yaitu terkait dengan fungsi dan keterampilan hidup.

Terkait dengan penelitian yang dilaksanakan penulis pada proses pembelajaran Bahasa di SDN 1 Kalapagunung yang dilaksanakan Guru Kelas bahwa teknik dan cara yang dilakukan masing-masing Guru kelas berbeda-beda sesuai variasi metode yang dipilih untuk mencapai tujuan pembelajaran yang diinginkan. Pada pembelajaran yang dilaksanakan 6 Guru Kelas di SDN 1 Kalapagunung diperoleh kenaikan hasil yang signifikan, dengan Rekap perolehan hasil sebagai berikut : 
FON ; Jurnal Pendidikan Bahasa dan Sastra Indonesia

Volume 13 Nomor 2 Tahun 2018

REKAP NILAI HASIL BELAJAR SISWA SDN 1 KALAPAGUNUNG

\begin{tabular}{|c|c|c|c|c|c|c|c|}
\hline $\begin{array}{l}\mathrm{N} \\
\mathrm{o}\end{array}$ & Nama Guru & $\frac{a}{d}$ & 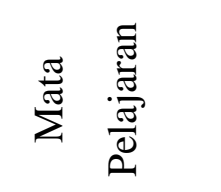 & Tema /Sub Tema & 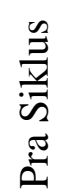 & $\frac{n}{3}$ & 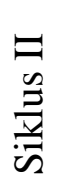 \\
\hline 1 & $\begin{array}{l}\text { MAMAH } \\
\text { SURYAMAH }\end{array}$ & $\mathrm{I}$ & B.Indonesia & $\begin{array}{l}\text { Tema } 1 \text { Diriku } \\
\text { ST 1.1 Aku dan } \\
\text { Teman Baru }\end{array}$ & 70 & 72 & 89 \\
\hline 2 & $\begin{array}{l}\text { NINA } \\
\text { SETIANI }\end{array}$ & II & B.Indonesia & $\begin{array}{l}\text { Tema } 2 \text { bermain di } \\
\text { lingkungan } \\
\text { ST } 2.1 \text { Bermain di } \\
\text { Rumah }\end{array}$ & 73 & 74 & 80 \\
\hline 3 & $\begin{array}{l}\text { UUM } \\
\text { UMIYATI }\end{array}$ & III & B.Indonesia & $\begin{array}{l}\text { Tema } 1 \text { Indahnya } \\
\text { kebersamaan } \\
\text { ST } 1.1 \text { Keragaman } \\
\text { Budaya Bangsaku }\end{array}$ & 70 & 75 & 86 \\
\hline 4 & $\begin{array}{l}\text { EMANUELL } \\
\text { A TURSINAH }\end{array}$ & IV & B.Indonesia & $\begin{array}{l}\text { Tema } 1 \text { Diriku } \\
\text { ST 1.1 Aku dan } \\
\text { Teman Baru }\end{array}$ & 60 & 73 & 85 \\
\hline 5 & $\begin{array}{l}\text { YOGA AJIE } \\
\text { PRATAMA }\end{array}$ & $\mathrm{V}$ & B.Indonesia & $\begin{array}{l}\text { Tema } 1 \text { Organ } \\
\text { Hewan-Manusia } \\
\text { ST } 1.1 \text { Organ } \\
\text { Hewan }\end{array}$ & 68 & 72 & 84 \\
\hline 6 & $\begin{array}{l}\text { IMAN } \\
\text { SUKIRMAN }\end{array}$ & VI & B.Indonesia & $\begin{array}{l}\text { Tema } 1 \text { Hiburan } \\
\text { ST } 1.1 \\
\text { Keberagaman }\end{array}$ & 65 & 70 & 75 \\
\hline
\end{tabular}




\begin{tabular}{|l|l|l|l|l|l|l|}
\hline & & & budaya & & & \\
\hline Jumlah & & & & 378 & 436 & 495 \\
\hline Rata - rata & & & & 68 & 73 & 84 \\
\hline Kriteria & & & & K & C & B \\
\hline
\end{tabular}

Pada Siklus I diperoleh nilai evaluasi belajar siswa rata-rata dari masing-masing Guru adalah 68 baru pencapaian pada Kategori Kurang. Hanya 68\% dari keberhasilan Kriteria Kelulusan Minimal yang ditentukan. Dan mengalami kenaikan dari perbaikan pada tindakan kedua (Siklus II) Nilai evaluasi yang diperoleh siswa mencapai rata-rata sebesar 84 yang berarti $84 \%$ nilai KKM dalam Kriteria Baik.

Dari data Nilai hasil pembelajaran yang diperoleh bahasa yang dilakukan Guru-guru dapat ditarik kesimpulan bahwa Pembelajaran bahasa yang menarik dengan metode dan teknik pembelajaran bervariasi akan meningkatkan kompetensi siswa terhadap pemahaman hasil belajar yang diinginkan
B. Internalisasi Literasi dalam

Pembelajaran Bahasa Indonesia

Literasi

merupakan kemampuan membaca dan menulis yang memiliki arti luas dan bermakna. yaitu kemampuan seseorang mengolah informasi menjadi sebuah konsep pemahaman ilmu pengetahuan, dalam artian tidak hanya sekedar tahu namun paham dan dapat mengolah serta mengembangankan sebuah pengetahuan, kepercayaan, kesenian, moral, hukum, adat istiadat menurut Taylor yang dikutip Fathoni (2006:237)

Tingkatan Literasi di Sekolah terhadap pembelajaran bahasa memiliki hubungan vertikal terhadap kualitas sekolah. Tingginya minat membaca buku Siswa sangat berpengaruh terhadap wawasan, mental dan prilaku Siswa tersebut. Ada banyak faktor kenapa tingkat Literasi disekolah 
sangat rendah, hal ini berkenaan dengan “ melek bacaan" yang masih kurang. yang menjadi budaya yang harus dijaga dan dilakukan menjadi pembiasaan yang tidak mustahil untuk pengembangan ilmu pengetahuan menjadi berhasil dan lebih maju dari sebelumnya

Aktivitas Literasi yang dibudayakan di $\quad$ SDN 1 Kalapagunung dikaitkan dengan pembelajaran bahasa di kelas memberikan acuan penilaian pada hasil observasi terhadap proses pembelajaran yang dilaksanakan dalam satu kali pembelajaran. Hasil penilaian aktivitas siswa pada Observasi pelaksanaan pembelajaran meningkat. Hal ini dapat dilihat pada perolehan hasil observasi pelaksanaaan pembelajara di kelas.

REKAP HASIL OBSERVASI PELAKSANAAN PEMBELAJARAN

\begin{tabular}{|c|c|c|c|c|c|c|}
\hline No & Nama Guru & Kelas & $\begin{array}{c}\text { Mata } \\
\text { Pelajaran }\end{array}$ & Tema /Sub Tema & $\begin{array}{l}\text { Siklus } \\
\text { I }\end{array}$ & $\begin{array}{c}\text { Siklus } \\
\text { II }\end{array}$ \\
\hline 1 & $\begin{array}{l}\text { Mamah } \\
\text { Suryamah }\end{array}$ & $\mathrm{I}$ & B.Indonesia & $\begin{array}{l}\text { Tema } 1 \text { Diriku } \\
\text { ST 1.1 Aku dan Teman } \\
\text { Baru }\end{array}$ & 70 & 76 \\
\hline 2 & Nina Setiani & II & B.Indonesia & $\begin{array}{l}\text { Tema } 2 \text { bermain di } \\
\text { lingkungan } \\
\text { ST } 2.1 \text { Bermain di Rumah }\end{array}$ & 73 & 72 \\
\hline 3 & $\begin{array}{l}\text { Uum } \\
\text { Umiyati }\end{array}$ & III & B.Indonesia & $\begin{array}{l}\text { Tema } 1 \text { Indahnya } \\
\text { kebersamaan } \\
\text { ST } 1.1 \text { Keragaman Budaya } \\
\text { Bangsaku }\end{array}$ & 70 & 79 \\
\hline 4 & Emanuella & IV & B.Indonesia & Tema 1 Diriku & 60 & 72 \\
\hline
\end{tabular}




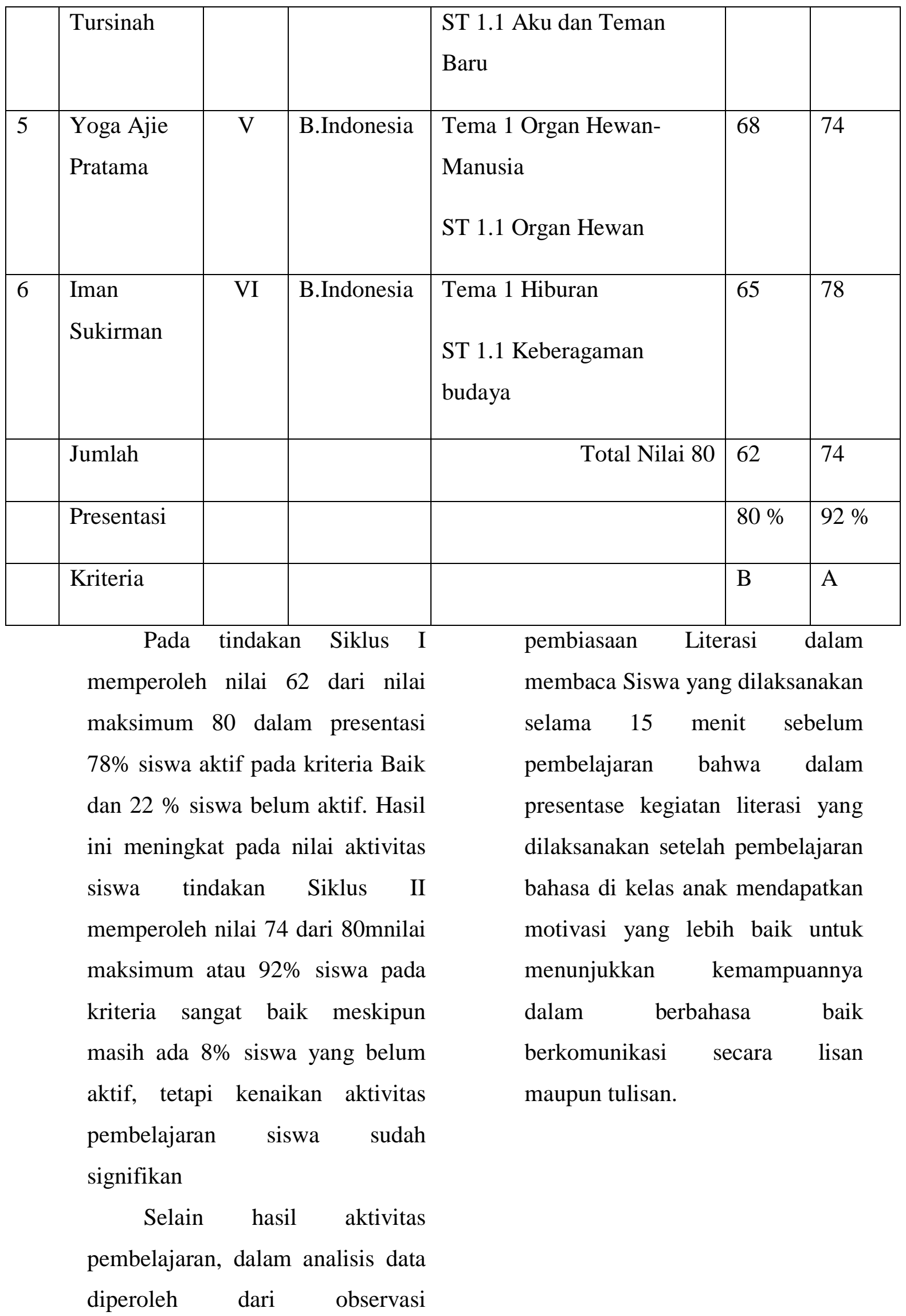


FON ; Jurnal Pendidikan Bahasa dan Sastra Indonesia

Volume 13 Nomor 2 Tahun 2018

\section{SIMPULAN}

Dengan demikian Pembelajaran

Berbahasa dengan intensitas pembelajaran yang menarik dan penggunaan metode dan teknik pembelajaran bervariasi jika dilaksanakan secara terus menerus oleh masing-masing Guru Kelas akan menjadi motivasi dorongan bagi siswa untuk lebih sering mengikuti kegiatan Literasi di Sekolah. Hal ini akan menunjang pada tingkat Kemampuan Litewrasi Siswa terutama dalam pemahaman, pengamatan dan penghayatan terhadap informasiinformasi yang diperoleh dan mengkomunikasikannya sebagai bahan dan bekal ilmu pengetahuannya di masa datang

\section{DAFTAR PUSTAKA}

Aunurrahman. 2009. Belajar dan

Pembelajaran. Bandung. Penerbit

Alfabeta

Machfudz, Imam. 2000. Metode

Pengajaran Bahasa

Indonesia Komunikatif. Jurnal

Bahasa dan Sastra UM

Salamun, M. 2002. Strategi Pembelajaran

Bahasa Arab di Pondok Pesantren.

Tesis.. Tidak diterbitkan

https://motivatorkreatif.wordpress.com/20

16/02/01/10-cara-mengembangkan-

budaya-literasi-di-sekolah

Nurhadi, Mulyani Ahmad.,1978.

"Pembinaan Minat Baca dan

Promosi Perpustakaan”. Berita

Perpustakaan Sekolah, 1 (5)

Wijono, 1981. “Bimbingan Membaca”.

Berita Perpustakaan Sekolah, (40) 